\title{
Front-page news
}

Nature Medicine's relationship with the press is probably not what you think it is.

$\mathbf{S}$ ometimes scientists accuse us of favoring the publication of papers that will catch the attention of the general press over studies with less headline-grabbing potential. "You prefer fluff over substance," the argument goes, and the accusations intensify whenever we publish an article that does happen to make the evening news.

As it turns out, we don't have any editorial mandate to have our papers make the front page of the newspaper. If they make it, we're certainly pleased, but this isn't what motivates us to publish one submission over another. If we wanted to make headlines, we would use a different publication strategy, as we have a good idea of what makes the popular press take notice when it comes to science.

Our press office keeps track of the coverage that papers from the Nature-branded and other nonclinical journals receive in 50 of the world's main news outlets, producing a weekly report for our internal use. In the first half of 2009, 16 'blockbuster' papers were picked up by at least 30 outlets. Of these, six were on fields other than biomedicine (for example, fossils or climate change). Of the remaining ten, three were on genetics (such as new gene links to brain diseases and cancer), five involved the use of primates (in fields ranging from infectious diseases to gene therapy), one was on the flu virus and one was on stem cells.

Even if we broaden our analysis beyond the blockbusters, the pattern is the same. When it comes to biomedicine, the media prefer disease genes, monkeys, infectious diseases (preferably the nasty ones with pandemic potential) and stem cells, because these are among the few fields that stand a chance of competing for readers' attention against the rest of the news. If we wanted to be media darlings, our average monthly issue would look very different from the way it currently does.

Journals are often also accused of creating hype around the papers they publish, seldom recognizing that the hype is often created by the authors' institutions. Many universities and companies have public-relations offices that send press releases describing their scientists' "success" in curing cancer, spinal-cord injury or HIV, even though the study in question may show therapeutic effects only in animal models of the disease.

This strategy is markedly different from that of our own press office, which sometimes even judges it necessary to 'un-hype' papers that may elicit inaccurate news coverage. In fact, our press officers often ask journal editors to summarize papers that we may not have otherwise written up in our weekly press releases just to ensure that the conclusions of the study are not misrepresented.

The proliferation of free, unfiltered sources of scientific news, such as blogs, further complicates the task of managing hype and preserving the accuracy of scientific information. Many years before the advent of digital media, the so-called 'Ingelfinger rule' partly served such a purpose. The rule, introduced in 1969 by Franz Ingelfinger at The New England Journal of Medicine, prevents authors from releasing the details of their work to the media before publication. The rule was put in place to allow time for the peer review of data before public consumption and to protect the originality of the journal's content.

The Nature journals, along with many others, observe the Ingelfinger rule, even though we hold periodic discussions on its usefulness, fairness and feasibility. This last point has become particularly relevant after the arrival of digital media, when hot findings discussed at a meeting can find their way almost instantaneously to a blog or Twitter feed. When people expect immediate access to information, are journals that observe Ingelfinger standing in the way?

It would be easy to ditch the Ingelfinger rule, but this could cause problems for some journals and their authors. For example, titles such as Nature, Science and Nature Medicine, which have journalists as part of their staff, currently have a firewall between their news and research sections. Removing Ingelfinger could lead to the elimination of this barrier and give journalists a competitive edge by granting them access to unpublished information. The news section might then cover those disease gene, monkey and stem cell studies rejected by the research editors, undermining any advantage the authors may have over researchers pursuing related projects and increasing their chances of being scooped.

Undeniably, the relationship between journals, scientists and the general press needs an overhaul, but there isn't an immediately obvious model suitable to the needs of all parties. What's clear is that the public's hunger for information and the availability of technologies that immediately satisfy this appetite make it urgent to find a new way forward. 